\title{
Cooking Class To Improve Geometry Recognition Ability In Early Children
}

\author{
Rini Alfiyah, Aldila Rahma, Reni Nurapriani
}

Received: 06042021 / Accepted: 29052021 / Published online: 30062021

(C) 2021 Association of Indonesian Islamic Early Childhood Education Study Program

\begin{abstract}
Abstrak Geometri merupakan bagian dari konsep dasar matematika yang penting bagi perkembangan anak usia dini, karena berhubungan dengan benda-benda di lingkungan sekitar anak. Kegiatan cooking class menjadi salah satu cara meningkatkan kemampuan mengenal geometri pada anak, melalui kegiatan mengolah makanan. Penelitian ini bertujuan untuk mengetahui pengaruh kegiatan cooking class terhadap peningkatan kemampuan mengenal bentuk geometri pada anak usia dini. Penelitian ini menggunakan pendekatan kuantitatif dengan metode Pre-Experimental berjenis One group pretestposttest. Populasi penelitian ini adalah siswa usia 5-6 tahun (kelompok B) berjumlah 15 anak dari Paud Al- Manshurin Kota Bandung. Pengumpulan data dilakukan melalui observasi, wawancara, dan dokumentasi. Dari hasil penelitian diperoleh nilai rata- rata pretest sebesar 2,1 dan nilai pot-test sebesar 3,3. Adapun uji t menunjukkan $\mathrm{t}$ hitung $>\mathrm{t}$ tabel $(17,429>1,761)$ dengan taraf signifikansi $5 \%$. Hasil tersebut menunjukkan bahwa kegiatan cooking class secara signifikan berpengaruh dalam meningkatkan kemampuan mengenal bentuk geometri pada anak.
\end{abstract}

Kata Kunci: geometri, cooking class, usia dini, pre eksperimental

\begin{abstract}
Geometry is one of the basic math concepts that are crucial for early childhood development because it relates to objects in the environment around children. Cooking class activity is one way to improve the ability to recognize geometry in children, through food processing activities. This study aims to determine the effect of cooking class activities on improving the ability to recognize geometric shapes in early childhood. This research uses a quantitative approach with the Pre-Experimental method, one group pretest-posttest type. The study population was students aged 5-6 years (group B) consist of 15 children from Paud Al-Manshurin, Bandung. Data collection was carried out through observation, interviews including documentation. From the research results, it was obtained that the pre-test average score was 2.1 and the post-test score was 3.3. The t-test shows $t$ value $>t$ table $(17.429>1.761)$ with a significance level of 5\%. These results indicate that cooking class activity significantly influences the child's ability to recognize geometric shape.
\end{abstract}

Keywords: geometry, cooking class, early childhood, pre experimental

\section{Pendahuluan}

Menurut Permendikbud Nomor 37 Tahun 2014, program bertujuan untuk mengembangkan dan menstimulasi berbagai aspek perkembangan anak yaitu aspek nilai agama dan moral, fisik-motorik, kognitif, bahasa, sosial-emosional, dan seni (Kementerian Pendidikan dan Kebudayaan Republik Indonesia, 2014). Salah satu konstruksi fundamental dalam perkembangan kognitif adalah mengenal bentuk. Anak mulai membentuk pemahaman konseptual tentang bentuk geometri di tahun-tahun awal kehidupannya (Clements, Sarama, Swaminathan, Weber, \& Trawick-Smith, 2018). Usia 3-6 tahun adalah periode signifikan 
penting untuk belajar benda geometri (Clements, Swaminathan, Hannibal, \& Sarama, 1999); (National Research Council, 2009).

Geometri adalah bidang matematika yang melibatkan bentuk, ukuran, posisi, arah, dan gerakan serta mendeskripsikan dan mengelompokkan lingkungan fisik tempat tinggal manusia. Pemahaman spasial pada anak adalah kesadaran tentang diri sendiri dalam kaitannya dengan orang dan objek di sekitar mereka (Copley, 2000). Geometri merupakan studi tentang ruang dan bentuk, seperti identifikasi objek dan mengelompokkan berdasarkan kriteria yang berbeda, memahami nama bentuk (persegi, segitiga, persegi panjang, dan lingkaran), dan penggunaan terlepas dari posisi atau ukurannya (Balinha \& Mamede, 2018). Hal ini menjadi acuan dasar mengapa pembelajaran geometri adalah salah satu bagian pembelajaran matematika yang penting diajarkan pada anak usia dini (Dahlan, 2014); (Sarama \& Clements, 2009).

Pembelajaran matematika terutama pengenalan bentuk geometri sampai saat ini masih jauh dari harapan dan kriteria pendidikan anak usia dini yaitu, bermain sambil belajar. Menurut Adolphus (2011), materi matematika yang dianggap sulit dan ditakuti siswa dalam pembelajaran matematika adalah materi geometri. Salah satu penyebab kesulitannya adalah belum disesuaikannya perkembangan berpikir siswa dengan materi yang diajarkan serta belum sesuai dengan tingkat perkembangan berpikir siswa (Safrina, Ikhsan, \& Ahmad, 2014). Dibutuhkan stimulasi dan pendekatan yang tepat dalam menerapkan pembelajaran yang efektif dan menyenangkan pada jenjang yang paling dasar, yaitu Pendidikan Anak Usia Dini (PAUD).

Berdasarkan hasil observasi awal yang peneliti lakukan di Paud Al- Manshurin Kota Bandung, diketahui bahwa kemampuan mengenal bentuk geometri anak masih rendah. Dari 15 peserta didik, 11 anak masih membutuhkan bimbingan dalam mengenal bentuk geometri. Pada umumnya, anak belum mampu menyebutkan nama bentuk geometri dengan benar. Selain konsep penamaan, anak juga masih belum mampu mengenali dan menyebutkan karakteristik, serta mengklasifikasikan benda berdasarkan bentuk geometri secara benar. Rendahnya kemampuan mengenal bentuk geometri pada anak kelompok B Paud Al- Manshurin salah satunya dipengaruhi oleh masih terbatasnya media pembelajaran yang tersedia yang berhubungan dengan pengenalan geometri. Metode pembelajaran yang digunakan kurang menarik serta kurang membangun minat anak dalam mengenal bentuk geometri.

Peneliti mencoba untuk melakukan kegiatan baru yang lebih menarik dalam pembelajaran matematika terutama mengenalkan geometri pada anak yaitu, melalui kegiatan cooking class. Cooking class atau kelas memasak dapat meningkatkan pengetahuan, keterampilan, serta motivasi anak. Kegiatan cooking class merupakan wahana yang tepat yang mampu menumbuhkan dan meningkatkan pengalaman belajar bagi anak secara langsung (Abdah \& Ulfah, 2013). Kegiatan ini sangat menarik, dimana anak akan belajar sambil bermain sehingga menimbulkan suasana yang menyenangkan. Memasak memberikan manfaat bagi anak yaitu memberi kesempatan untuk berkonsentrasi, melatih konsep-konsep matematika, berkarya, bereksperimen, dan berbagi (Amidjaja, 2007). Kegiatan cooking class diharapkan dapat dijadikan sebagai salah satu metode dalam meningkatkan kemampuan mengenal bentuk geometri anak. Berdasarkan latar belakang tersebut, penelitian ini bertujuan untuk mengetahui pengaruh kegiatan cooking class dalam meningkatkan kemampuan mengenal bentuk geometri pada anak usia 5-6 tahun di Paud Al- Manshurin, Kota Bandung.

Dari penelitian-peneliyian yang sudah dilakukan sebelumnya, ada berbagai bentuk aktivitas lain yang dapat diperkenalkan pada anak untuk mengenal bentuk geometri. Penelitian yang dilakukan oleh Rachmat \& Sumiati (2016), melalui permaianan harta karun yaitu, mencari benda yang disembunyikan (hidden object). Bermain menjadi metode yang umum digunakan dalam pengenalan geometri pada anak, dimana didalamnya melibatkan kegiatan mengelompokkan, memasangkan, dan mengenal bentuk geometri sekitar anak (Mariati, Syukri, \& Marmawi, 2014). Permainan balok menjadi salah satu metode yang sering digunakan untuk mengenalkan geometri. Media balok memiliki bentuk geometri dan warna beragam sehingga dapat menyenangkan bagi anak (Hasanah \& Agung, 2019). 


\section{Metode}

Penelitan menggunakan pendekatan kuantitatif dengan metode eksperimen. Desain penelitian yang digunakan dalam penelitian ini adalah pre-eksperimen dengan jenis one group pretest-postest. Penelitian ini melakukan pre-test sebelum perlakuan (treatment) dan post test setelah perlakuan pada kelompok yang sama, kemudian hasil keduanya dibandingkan (Sugiyono, 2019).

Populasi penelitian adalah siswa kelas B PAUD Al-Manshurin Kota Bandung, berjumlah 15 anak dengan usia 5-6 tahun (Kelompok B) pada tahun ajaran 2018-2019. Pengumpulan data dilakukan melalui observasi kegiatan pembelajaran secara langsung, wawancara dengan guru, dan dokumentasi. Adapun aspek yang diamati pada anak adalah karakteristik bentuk geometri, identifikasi bentuk geometri, dan klasifikasi benda berdasarkan bentuk geometri (National Council of Teachers of Mathematics, 2000); (Kementerian Pendidikan dan Kebudayaan Republik Indonesia, 2014). Perlakuan (treatment) dilakukan sebanyak 5 kali dalam kurun waktu 1 bulan, sebelum ditutup denga post test. Skala pengukuran yang digunakan dalam memberi nilai pada penelitian ini yaitu Rating Scale. Skala ini dibagi menjadi empat kategori yaitu, Belum Berkembang/ BB (skor 1), Mulai Berkembang/ MB (skor 2), Berkembang Sesuai Harapan/ BSH (skor 3), dan Berkembang Sangat Baik/ BSB (skor 4) (PAUD Jateng, 2015).

\section{Hasil Penelitian dan Pembahasan}

Sebagaimana yang telah disebutkan di bagian metodologi, sebelum memberi perlakukan kegiatan cooking class, peneliti melakukan pre test terlebih dahulu. Berikut adalah hasil pre test kemampuan mengenal bentuk geometri pada anak kelas B Paud AlManshurin, Kota Bandung.

Tabel 1. Hasil Pre Test Kemampuan Mengenal Bentuk Geometri Siswa Kelompok B Paud Al Manshurin, Kota Bandung

\begin{tabular}{|c|c|c|c|c|c|c|c|}
\hline \multirow{2}{*}{ No. } & \multirow[t]{2}{*}{ Nama } & \multicolumn{4}{|c|}{ Kategori Indikator } & \multirow{2}{*}{ Jumlah } & \multirow{2}{*}{ Rata-rata } \\
\hline & & 1 & 2 & 3 & 4 & & \\
\hline 1. & AAM & 2 & 1 & 2 & 3 & 8 & 2 \\
\hline 2. & ARN & 1 & 2 & 2 & 3 & 8 & 2 \\
\hline 3. & AI & 2 & 2 & 3 & 3 & 10 & 2,5 \\
\hline 4. & AI & 2 & 2 & 3 & 3 & 10 & 2,5 \\
\hline 5. & APA & 1 & 1 & 1 & 3 & 6 & 1,5 \\
\hline 6. & HMP & 3 & 3 & 3 & 3 & 12 & 3 \\
\hline 7. & LM & 2 & 2 & 2 & 3 & 9 & 2,25 \\
\hline 8. & MAZ & 2 & 2 & 3 & 3 & 10 & 2,5 \\
\hline 9. & MAA & 2 & 2 & 3 & 3 & 10 & 2,5 \\
\hline 10. & MRN & 1 & 1 & 1 & 3 & 6 & 1,5 \\
\hline 11. & NPA & 1 & 2 & 2 & 3 & 8 & 2 \\
\hline 12. & OPK & 1 & 1 & 1 & 2 & 5 & 1,25 \\
\hline 13. & RDA & 1 & 1 & 3 & 2 & 7 & 1,75 \\
\hline 14. & RFP & 2 & 1 & 2 & 3 & 8 & 2 \\
\hline 15. & RW & 1 & 2 & 2 & 3 & 8 & 2 \\
\hline \multicolumn{2}{|c|}{ Jumlah } & 24 & 25 & 33 & 43 & \multicolumn{2}{|c|}{125} \\
\hline \multicolumn{2}{|c|}{ Rata-rata } & 1,6 & 1,7 & 2,2 & 2,9 & \multicolumn{2}{|c|}{2,1} \\
\hline
\end{tabular}

Keterangan angka kategori indikator:

1: Anak mampu menyebutkan bentuk geometri

2: Anak mampu menyebutkan karakteristik bentuk geometri

3: Anak dapat mengenali bentuk geometri

4: Anak dapat mengklasifikasikan berdasarkan bentuk geometri 
Berdasarkan tabel 1, nilai pre test menunjukkan skor terbesar 12 dan skor terkecil 5 dengan nilai rata- rata 2,1 . Untuk lebih jelasnya, berikut adalah prosentase hasil observasi kemampuan mengenal bentuk geometri anak pada tahap pre-test.

Berdasarkan tabel 1, nilai pre test menunjukkan skor terbesar 12 dan skor terkecil 5 dengan nilai rata- rata 2,1 . Untuk lebih jelasnya, berikut adalah prosentase hasil observasi kemampuan mengenal bentuk geometri anak pada tahap pre-test.

Tabel 2. Hasil Observasi Kemampuan Mengenal Bentuk Geometri Siswa

Kelompok B di Paud Al- Manshurin pada Pre Test

\begin{tabular}{|c|l|c|c|c|c|}
\hline \multirow{2}{*}{ No. } & \multicolumn{1}{|c|}{ Indikator } & \multicolumn{4}{c|}{ Jumlah Anak } \\
\cline { 3 - 6 } & \multicolumn{1}{|c|}{ BB } & MB & BSH & BSB \\
\hline 1. & $\begin{array}{l}\text { Anak mampu menyebutkan bentuk } \\
\text { geometri }\end{array}$ & 7 & 7 & 1 & \\
\hline 2. & $\begin{array}{l}\text { Anak mampu menyebutkan } \\
\text { karakteristik bentuk geometri }\end{array}$ & 6 & 8 & 1 & \\
\hline 3. & $\begin{array}{l}\text { Anak dapat mengenali bentuk } \\
\text { geometri }\end{array}$ & 3 & 6 & 6 & \\
\hline 4. & $\begin{array}{l}\text { Anak dapat mengklasifikasikan } \\
\text { berdasarkan bentuk geometri }\end{array}$ & & 2 & 13 & \\
\hline \multicolumn{2}{|c|}{ Jumlah } & 16 & 23 & 21 & $0 \%$ \\
\hline
\end{tabular}

Keterangan penilaian berdasarkan rating scale

BB : Belum Berkembang

MB : Mulai Berkembang

BSH : Berkembang Sesuai Harapan

BSB : Berkembang Sangat Baik

Hasil observasi pre test kemampuan mengenal bentuk geometri kelompok B belum mencapai perkembangan yang baik. Masih ada anak yang Belum Berkembang sebesar $27 \%$. Anak yang Mulai Berkembang 38\% dan sebesar 35\% anak Berkembang Sesuai Harapan. Adapun anak dengan kemampuan Berkembang Sangat Baik Masih 0\%. Oleh karena itu, perlu diberikan treatment kegiatan yang mampu meningkatkan kemampuan mengenal bentuk geometri pada anak.

Pelaksanaan perlakuan (treatment) yaitu berupa praktik langsung cooking class dilakukan lima kali dengan intensitas pertemuan dua kali seminggu. Adapun bentuk geometri yang diperkenalkan pada anak adalah bentuk persegi, persegi panjang, segitiga, dan lingkaran. Peneliti memberi contoh dan mengobservasi anak pada saat kegiatan berlangsung. Treatment pertama, kegiatan membuat Cireng (makanan tradisional dari tepung tapioka atau kanji yang digoreng). Treatment kedua, memotong buah sesuai bentuk geometri kemudian dibuat sate buah. Treatment ketiga yaitu membuat sandwich. Anak belajar mengenal bentuk geometri dari roti yang diptotong menjadi segitiga, sosis dipotong menjadi bentuk persegi panjang, keju dipotong menjadi bentuk persegi, dan tomat serta timun yang dipotong menjadi bentuk lingkaran. Setelah itu, anak diminta untuk menyusun sandwich masing-masing. Treatment keempat, membuat sop buah bentuk geometri dimana anak diminta menunagkan buah ke dalam mangkok sambil menyebutkan satu per satu bentuknya. Treatment kelima, anak kembali membuat sandwich namun dengan bahan yang berbeda dengan sebelumnya. Sambil membuat sandwich, peneliti menanyakan bentuk-bentuk geometri pada anak-anak.

Setelah semua treatment selesai dilaksanakan, peneliti kemudian mengadakan post test. Berikut ini adalah hasil post test kemampuan mengenal bentuk geometri kelompok B Paud AlManshurin. 
Tabel 3. Hasil Post Test Kemampuan Mengenal Bentuk Geometri

Kelompok B di Paud Al- Manshurin pada Post-test

\begin{tabular}{|c|c|c|c|c|c|c|c|}
\hline \multirow{2}{*}{ No. } & \multirow{2}{*}{ Nama } & \multicolumn{4}{|c|}{ Kategori Aspek Penilaian } & \multirow{2}{*}{ Jumlah } & \multirow{2}{*}{ Rata-rata } \\
\hline & & 1 & 2 & 3 & 4 & & \\
\hline 1. & AAM & 3 & 2 & 4 & 4 & 13 & 3,25 \\
\hline 2. & ARN & 3 & 3 & 4 & 4 & 14 & 3,5 \\
\hline 3. & $\mathrm{AI}$ & 4 & 3 & 4 & 4 & 15 & 3,75 \\
\hline 4. & $\mathrm{AI}$ & 3 & 3 & 3 & 4 & 13 & 3,25 \\
\hline 5. & APA & 3 & 2 & 3 & 4 & 12 & 3 \\
\hline 6. & HMP & 4 & 4 & 4 & 4 & 16 & 4 \\
\hline 7. & LM & 4 & 3 & 4 & 4 & 15 & 3,75 \\
\hline 8. & MAZ & 3 & 3 & 4 & 4 & 14 & 3,5 \\
\hline 9. & MAA & 3 & 3 & 4 & 4 & 14 & 3,5 \\
\hline 10. & MRN & 2 & 2 & 2 & 4 & 10 & 2,5 \\
\hline 11. & NPA & 3 & 3 & 3 & 4 & 13 & 3,25 \\
\hline 12. & OPK & 2 & 2 & 2 & 3 & 9 & 2,25 \\
\hline 13. & RDA & 4 & 3 & 4 & 3 & 14 & 3,5 \\
\hline 14. & RFP & 3 & 2 & 4 & 4 & 13 & 3,25 \\
\hline 15. & RW & 3 & 3 & 3 & 4 & 13 & 3,25 \\
\hline & Jumlah & 47 & 42 & 52 & 58 & & 199 \\
\hline & Rata-rata & 3,1 & 2,8 & 3,4 & 3,9 & & 3,3 \\
\hline
\end{tabular}

Keterangan angka kategori indikator:

1: Anak mampu menyebutkan bentuk geometri

2: Anak mampu menyebutkan karakteristik bentuk geometri

3: Anak dapat mengenali bentuk geometri

4: Anak dapat mengklasifikasikan berdasarkan bentuk geometri

Berdasarkan hasil observasi anak setelah diberikan treatment, diperoleh hasil sebagai berikut:

Tabel 4. Hasil Observasi Kemampuan Mengenal Bentuk Geometri Kelompok B di Paud Al- Manshurin pada Post Test

\begin{tabular}{|c|l|c|c|c|c|}
\hline \multirow{2}{*}{ No. } & \multicolumn{1}{|c|}{ Indikator } & \multicolumn{4}{c|}{ Jumlah Anak } \\
\cline { 3 - 5 } & BB & MB & BSH & BSB \\
\hline 1. & $\begin{array}{l}\text { Anak mampu menyebutkan } \\
\text { bentuk geometri }\end{array}$ & 2 & 9 & 4 \\
\hline 2. & $\begin{array}{l}\text { Anak mampu menyebutkan } \\
\text { karakteristik bentuk geometri }\end{array}$ & & 5 & 9 & 1 \\
\hline 3. & $\begin{array}{l}\text { Anak dapat mengenali bentuk } \\
\text { geometri }\end{array}$ & 2 & 4 & 9 \\
\hline 4. & $\begin{array}{l}\text { Anak dapat mengklasifikasikan } \\
\text { berdasarkan bentuk geometri }\end{array}$ & & & 2 & 13 \\
\hline & $\quad$ Jumlah & $0 \%$ & $15 \%$ & $40 \%$ & $45 \%$ \\
\hline
\end{tabular}

Keterangan penilaian berdasarkan rating scale

BB : Belum Berkembang

MB : Mulai Berkembang

BSH : Berkembang Sesuai Harapan

BSB : Berkembang Sangat Baik

Tabel 4 menjelaskan bahwa kemampuan mengenal bentuk geometri siswa kelompok B setelah diberi perlakuan mengalami peningkatan dengan berkurangnya persentase anak yang Belum Berkembang dari 27\% menjadi 0\%. Anak yang Mulai Berkembang mengalami 
penurunan yang cukup drastis dari persentase $38 \%$ menjadi $15 \%$. Anak yang Berkembang sesuai Harapan meningkat dari 35\% menjadi $40 \%$. Adapun anak yang Berkembang Sangat Baik mengalami peningkatan tajam dari $0 \%$ menjadi $45 \%$. Berikut ini adalah tabel hasil perbandingan pre-test dan post-test kemampuan mengenal bentuk geometri siswa kelompok B Paud Al-Manshurin.

Tabel 5. Hasil Uji t (t-Test) Selisih Pre-test dan Post-test Kemampuan Mengenal Bentuk Geometri

\begin{tabular}{|c|c|c|c|c|c|c|}
\hline No. & Nama & Pre-test & Post-test & $\begin{array}{c}\text { Gaind (d) } \\
\text { (selisih) }\end{array}$ & $\begin{array}{c}\text { Xd } \\
\text { (d-Md) }\end{array}$ & $\sum \mathbf{x}^{2} \mathbf{d}$ \\
\hline 1. & $\overline{\mathrm{AAM}}$ & 2 & 3,25 & 1,25 & 0,03 & 0,001 \\
\hline 2. & ARN & 2 & 3,5 & 1,5 & 0,28 & 0,080 \\
\hline 3. & $\mathrm{AI}$ & 2,5 & 3,75 & 1,25 & 0,03 & 0,001 \\
\hline 4. & AI & 2,5 & 3,25 & 0,75 & $-0,47$ & 0,218 \\
\hline 5. & APA & 1,5 & 3 & 1,5 & 0,28 & 0,080 \\
\hline 6. & HMP & 3 & 4 & 1 & $-0,22$ & 0,047 \\
\hline 7. & LM & 2,25 & 3,75 & 1,5 & 0,28 & 0,080 \\
\hline 8. & MAZ & 2,5 & 3,5 & 1 & $-0,22$ & 0,047 \\
\hline 9. & MAA & 2,5 & 3,5 & 1 & $-0,22$ & 0,047 \\
\hline 10. & MRN & 1,5 & 2,5 & 1 & $-0,22$ & 0,047 \\
\hline 11. & NPA & 2 & 3,25 & 1,25 & 0,03 & 0,001 \\
\hline 12. & OPK & 1,25 & 2,25 & 1 & $-0,22$ & 0,047 \\
\hline 13. & RDA & 1,75 & 3,5 & 1,75 & 0,53 & 0,284 \\
\hline 14. & RFP & 2 & 3,25 & 1,25 & 0,03 & 0,001 \\
\hline \multirow[t]{3}{*}{15.} & RW & 2 & 3,25 & 1,25 & 0,03 & 0,001 \\
\hline & Jumlah & 31,25 & 49,5 & 18,25 & $-0,05$ & 0,983 \\
\hline & Rata- rata & 2,1 & 3,3 & 1,22 & $-0,003$ & 0,066 \\
\hline
\end{tabular}

Keterangan:

$$
\begin{array}{ll}
\sum \mathrm{d} & : \text { selisih } \\
\mathrm{Xd} & : \text { selisih masing- masing subjek } \\
\sum \mathrm{X}^{2} \mathrm{~d} & : \text { jumlah kuadrat deviasi } \\
\mathrm{Md} & : \text { Mean dari perbedaan pre-test post-test }
\end{array}
$$

Tabel 5 menunjukkan terjadi peningkatan hasil post test dibandingkan hasil pre test. Skor rata-rata pre-test dari 2,1 meningkat menjadi 3,3 dengan selisih rata-rata skor 1,22. Berdasarkan tabel tersebut, peningkatan yang paling tinggi dicapai oleh RDA dengan selisih skor rata-rata 1,75, sedangkan anak yang peningkatannya tidak terlalu signifikan adalah AI, dengan selisih skor 0,75 .

Dari hasil pengujian dengan uji-t, setelah nilai $t$ hitung diketahui $(t=17,429)$, selanjutnya nilai tersebut dibandingkan dengan tabel distribusi t $(\alpha=5 \%)$ dengan derajat kebebasan Db (n-1)=14. Dari tabel distribusi t, diperoleh taraf signifikansi 1,761. Berdasarkan perhitungan diperoleh perbandingan hasil pre-test dan post-test dengan $\mathrm{t}_{\text {hitung }}>\mathrm{t}_{\text {tabel }}(17,429>1,761)$. Hasil ini membuktikan bahwa kegiatan cooking class berpengaruh signifikan dalam meningkatkan kemampuan mengenal bentuk geometri pada anak usia 5-6 tahun di Paud Al- manshurin Kota Bandung pada tahun ajaran 2018-2019.

Menurut informasi yang diperoleh dari guru kelas pada saat observasi awal, salah satu kendala dalam mengenalkan geometri pada anak yaitu metode dan media pembelajaran yang tidak bervariasi. Hasil penelitian ini membuktikan bahwa anak lebih tertarik kegiatan cooking class, dimana anak selain mendengarkan penjelasan guru juga terlibat aktif dalam pembelajaran dengan cara praktik langsung membuat makanan.

Treatment pada penelitian ini adalah peneliti mengajak anak-anak mengenal bahan yang akan dimasak kemudian "memasak" sesuai dengan menu yang sudah disepakati pada 
hari itu. Peneliti memberi contoh bagaimana prosedur memasak sambil mengenalkan bentuk geometri melalui makanan yang sedang dibuat. Di tengah kegiatan cooking class, peneliti kemudian mengobservasi kemampuan anak dalam mengenal bentuk geometri. Identifikasi kemampuan anak berdasarkan seberapa baik anak dalam membedakan bentuk geometri secra akurat (Clements et al., 2018). Cooking class membuat anak antusias dan semangat mengikuti pelajaran, sebab kegiatan ini berbeda dengan yang biasa dilakukan di Paud AlManshurin.

Perlakukan pada panelitian ini dibuat lebih bervariasi agar dapat meningkatkan motivasi anak dalam belajar. Kemampuan anak dalam mengenal geometri meningkat dari pertemuan satu ke pertemuan berikutnya. Terlihat dari antusiasme anak ketika mereka membantu peneliti menyiapkan bahan-bahan untuk memasak, membantu peneliti memasukkan adonan bahan masakan serta antusiasme mereka ketika membuat bentuk geometri dari masakan yang mereka buat. Hal ini sejalan dengan penelitian yang dilakukan (Maula \& Setyowati, 2016). Metode bermain berbasis fun cooking adalah wahana atau sarana pembelajaran untuk membantu anak dalam mengenal bentuk geometri melalui kegiatan membuat makanan sederhana. Metode bermain fun cooking dianggap tepat, menarik ,dan menyenangkan bagi anak sehingga anak dapat mengembangkan kemampuan kognitif dalam mengenal bentuk geometri.

Kegiatan cooking class di Paud Al- Manshurin sebelumnya hanya sekedar mengaduk teh atau membuat roti selai. Dalam pada penelitian ini, cooking class dijadikan sarana untuk meningkatkan kemampuan perkembangan siswa, yaitu kemampuan mengenal bentuk geometri. Peneliti memperkenalkan bentuk geometri melalui bahan makanan yang akan dibuat. Hal ini menjadi sesuatu yang baru, karena biasanya anak mengenal bentuk geometri melalui gambar dari buku. Peneliti juga memberi kesempatan pada anak untuk mencoba membuat sendiri makanan yang akan dimasak. Bahan makanan tersebut dipotong, dicetak, dan dibentuk sesuai bentuk geometri. Anak menjadi lebih antusias dan tertarik karena mereka dapat bereksperimen membuat makanan sendiri. Terlebih lagi, mereka dapat menikmati hasil masakan buatan mereka sendiri. Kegiatan cooking class membantu anak dalam memvisualisasikan dan mendeskripsikan bentuk geometri. Hal ini sesuai dengan tingkat belajar geometri dari model Van Hiele, yaitu tingkat visual (level 1) dan tingkat deskriptif atau analisis (level 2) (Balinha \& Mamede, 2018).

Sesuai penelitian Abdah \& Ulfah (2013), cooking class adalah wahana yang tepat untuk anak TK yang mampu menumbuhkan dan meningkatkan pengelaman belajar anak secara langsung. Kegiatan cooking class sangat menarik dan memungkinkan anak akan belajar sambil bermain sehingga menimbulkan suasana yang menyenangkan. Pedoman kurikulum PAUD mengacu pada kebutuhan anak akan proses pedagogis yang bersifat menyenangkan (Balinha \& Mamede, 2018). Memasak memberikan manfaat bagi anak yaitu memberi kesempatan untuk berkonsentrasi, melatih konsep matematika, berkarya, bereksperimen dan berbagi (Amidjaja, 2007). Selain itu, tentunya anak dapat belajar konsep matematika secara langsung dalam belajar mengenal bentuk geometri melalui makanan yang mereka bentuk. Selain meningkatkan kemampuan geometri anak, menurut Montolalu kegiatan cooking class memiliki manfaat lain antara lain mengembangkan ekspresi, mengembangkan imajinasi, melatih motorik kasar dan halus, melatih kecakapan alam mengkombinasikan warna, serta menunjuk perasaan pada gerakan tangan (Abdah \& Ulfah, 2013)

Hasil penelitian lain terkait peningkatan mengenal bentuk geometri menggunakan metode berbeda, juga menunjukkan keberhasilan. Penelitian yang dilakukan Hasanah \& Agung (2019) menggunakan media balok, menunjukkan bahwa anak mampu mengenal, mengelompokkan berdasarkan kriteria, mencocokkan benda geometri, dan membangun sesuatu menggunakan media balok, dengan tingkat keberhasilan sebesar $80,97 \%$. Penelitian lain menggunakan aktivitas bermain mencari "harta karun", dapat mengembangkan kemampuan menganalisis bentuk dan warna serta membantu daya imajinasi anak (Rachmat \& Sumiati, 2016). Kegiatan bermain menggunakan balok, puzzle geometri, kartu geometri, menempel, menjiplak, dan 
dengan bantuan lembar kerja anak juga dapat meningkatkan pemahaan anak terhadap konsep geometri (Mariati et al., 2014). Kesamaan dari penelitian-peneliatian yang berhubungan dengan peningkatan kemampuan geometri adalah melalui permainan. Keseriusan dan pentingnya konten yang diperkenalkan pada anak tidak akan berkurang ketika dilakukan dengan permainan. Kegiatan bermain justru sangat diperlukan bagi perkembangan anak (Dallabona \& Mendes, 2004).

\section{Simpulan dan Saran}

Penerapan kegiatan cooking class pada anak usia 5-6 tahun di Paud Al- Manshurin Bandung pada tahun ajaran 2018-2019 berpengaruh dalam meningkatkan kemampuan mengenal bentuk geometri anak. Perbedaan skor rata-rata pre test dan post test berdasarkan hasil uji-t yaitu, $\mathrm{t}$ hitung $>\mathrm{t}$ tabel $(17,429>1,761)$. Oleh karena itu, hasil penelitian ini dinyatakan signifikan. Peningkatan kemampuan anak dalam mengenal bentuk geometri dapat dilihat dari peningkatan prosentase anak kategori Berkembang Sesuai Harapan (BSH) meningkat dari 35\% menjadi 40\%, dan kategori Berkembang Sangat Baik (BSB) dari 0\% meningkat menjadi $45 \%$.

Penggunaan teknik cooking class dengan praktik langsung merupakan salah satu cara yang cukup efektif untuk meningkatkan kemampuan mengenal bentuk geometri anak usia 5-6 tahun di Paud Al- Manshurin pada tahun ajaran 2018-2019.

\section{Daftar Rujukan}

Abdah, R., \& Ulfah, M. (2013). Kegiatan Cooking Class Untuk Meningkatkan Kemampuan Motorik Halus Kelompok B TK Success Kecamatan Rungkut Surabaya. PAUD Teratai, 2(1). Retrieved from https://jurnalmahasiswa.unesa.ac.id/index.php/paudteratai/article/view/1273

Adolphus, T. (2011). Problems of Teaching and Learning of Geometry in Secondary Schools in Rivers State, Nigeria. International Journal of Emerging. Sciences, 1(2), 143-152.

Amidjaja, A. (2007). 101 Fun and Mind Stimulating Things to do with Your Kids (2 - 6 years). Jakarta: PT Elex Media Komputind.

Arikunto, S. (2013). Prosedur Penelitian Suatu Pendekatan Praktik. Jakarta: Rineka Cipta.

Balinha, F., \& Mamede, E. (2018). Young children working with geometric figures. Journal of the European Teacher Education Network, 13(0), 11-22. Retrieved from https://www.semanticscholar.org/paper/Young-children-working-with-geometric-figuresBalinha-Mamede/5f21c9f99daf709b43f795b36d91689815f19ff6

Clements, D. H., Sarama, J., Swaminathan, S., Weber, D., \& Trawick-Smith, J. (2018). Teaching and learning Geometry: early foundations. Quadrante, XXVII(2), 7-31.

Clements, D. H., Swaminathan, S., Hannibal, M. A. Z., \& Sarama, J. (1999). Young Children's Concepts of Shape. Journal for Research in Mathematics Education, 30(2), 192-212. https://doi.org/10.2307/749610

Copley, J. V. (2000). Geometry and Spatial Sense in the Early Childhood Curriculum. In The Young Child and Mathematics (Naeyc) (2nd ed., pp. 105 - 124). Retrieved from http://earlygeometry-shape.weebly.com/uploads/2/0/7/5/20752418/geometry.2.pdf

Dahlan, J. A. (2014). Analisis Kurikulum Matematika. In Kurikulum dan Pengembangannya (1st ed., pp. 1-34). Retrieved from http://repository.ut.ac.id/id/eprint/4373

Dallabona, S. R., \& Mendes, S. M. S. (2004). O-Ldico-Na-Educao-Infantil. Revista de Divulgação Técnico-Científica Do ICPG, 1(4), 13. Retrieved from https://conteudopedagogico.files.wordpress.com/2011/02/o-ldico-na-educao-infantil.pdf

Hasanah, L., \& Agung, S. (2019). Kemampuan Pengenalan Geometri Melalui Kegiatan Bermain Balok Anak Usia 5-6 Tahun. JECE (Journal of Early Childhood Education), 1(2), 45-52. https://doi.org/10.17509/jpa.v2i2.24538

Kementerian Pendidikan dan Kebudayaan Republik Indonesia. Peraturan Menteri Pendidikan dan Kebudayaan Nomor 137 Tahun 2014. Tentang Standar Nasional Pendidikan Anak Usia Dini. , (2014). 
Mariati, Syukri, M., \& Marmawi, R. (2014). Penerapan Metode Bermain dalam Pengenalan Konsep Geometri Pada Anak Usia 3-4 Tahun. Jurnal Pendidikan Dan Pembelajaran Khatulistiwa, 3(6), 1-10. Retrieved https://jurnal.untan.ac.id/index.php/jpdpb/article/view/5510/6298

Maula, N. I. I., \& Setyowati, S. (2016). Pengaruh Metode Bermain Berbasis Fun Cooking Terhadap Kemampuan Mengenal Bentuk Geometri Anak Kelompok A. PAUD Teratai, 5(2). Retrieved from https://jurnalmahasiswa.unesa.ac.id/index.php/paudteratai/article/view/14845

National Council of Teachers of Mathematics. (2000). Principles and standards for school mathematics. Reston, VA: National Council of Teachers of Mathematics.

National Research Council. (2009). Mathematics learning in early childhood: Paths Toward Excellence and Equity (C. T. Cross, T. A. Woods, \& H. Schweingruber, Eds.). Retrieved from http://math4all.onmason.com/wp-content/blogs.dir/1543/files/2014/09/Mathlearning-in-Early-Childhood.pdf

PAUD Jateng. (2015). Contoh Format Checklist Skala Capaian Perkembangan PAUD. Retrieved December 18, 2020, from https://www.paud.id/format-skala-capaianperkembangan-paud/

Rachmat, N. A., \& Sumiati, T. (2016). Peningkatan Kemampuan Mengenal Geometri Pada Anak Usia Dini Melalui Permainan Mencari Harta Karun. Metodik Didaktik, 11(1), 7181. https://doi.org/https://doi.org/10.17509/md.v11i1.3787

Abdah, R., \& Ulfah, M. (2013). Kegiatan Cooking Class Untuk Meningkatkan Kemampuan Motorik Halus Kelompok B TK Success Kecamatan Rungkut Surabaya. PAUD Teratai, 2(1). Retrieved from https://jurnalmahasiswa.unesa.ac.id/index.php/paudteratai/article/view/1273

Adolphus, T. (2011). Problems of Teaching and Learning of Geometry in Secondary Schools in Rivers State, Nigeria. International Journal of Emerging. Sciences, 1(2), 143-152.

Amidjaja, A. (2007). 101 Fun and Mind Stimulating Things to do with Your Kids (2 - 6 years). Jakarta: PT Elex Media Komputind.

Arikunto, S. (2013). Prosedur Penelitian Suatu Pendekatan Praktik. Jakarta: Rineka Cipta.

Balinha, F., \& Mamede, E. (2018). Young children working with geometric figures. Journal of the European Teacher Education Network, 13(0), 11-22. Retrieved from https://www.semanticscholar.org/paper/Young-children-working-with-geometric-figuresBalinha-Mamede/5f21c9f99daf709b43f795b36d91689815f19ff6

Clements, D. H., Sarama, J., Swaminathan, S., Weber, D., \& Trawick-Smith, J. (2018). Teaching and learning Geometry: early foundations. Quadrante, XXVII(2), 7-31.

Clements, D. H., Swaminathan, S., Hannibal, M. A. Z., \& Sarama, J. (1999). Young Children's Concepts of Shape. Journal for Research in Mathematics Education, 30(2), 192-212. https://doi.org/10.2307/749610

Copley, J. V. (2000). Geometry and Spatial Sense in the Early Childhood Curriculum. In The Young Child and Mathematics (Naeyc) (2nd ed., pp. 105 - 124). Retrieved from http://earlygeometry-shape.weebly.com/uploads/2/0/7/5/20752418/geometry.2.pdf

Dahlan, J. A. (2014). Analisis Kurikulum Matematika. In Kurikulum dan Pengembangannya (1st ed., pp. 1-34). Retrieved from http://repository.ut.ac.id/id/eprint/4373

Dallabona, S. R., \& Mendes, S. M. S. (2004). O-Ldico-Na-Educao-Infantil. Revista de Divulgação Técnico-Científica Do ICPG, 1(4), 13. Retrieved from https://conteudopedagogico.files. wordpress.com/2011/02/o-ldico-na-educao-infantil.pdf

Hasanah, L., \& Agung, S. (2019). Kemampuan Pengenalan Geometri Melalui Kegiatan Bermain Balok Anak Usia 5-6 Tahun. JECE (Journal of Early Childhood Education), 1(2), 45-52. https://doi.org/10.17509/jpa.v2i2.24538

Kementerian Pendidikan dan Kebudayaan Republik Indonesia. Peraturan Menteri Pendidikan dan Kebudayaan Nomor 137 Tahun 2014. Tentang Standar Nasional Pendidikan Anak Usia Dini. , (2014). 
Mariati, Syukri, M., \& Marmawi, R. (2014). Penerapan Metode Bermain dalam Pengenalan Konsep Geometri Pada Anak Usia 3-4 Tahun. Jurnal Pendidikan Dan Pembelajaran Khatulistiwa, 3(6), 1-10. Retrieved https://jurnal.untan.ac.id/index.php/jpdpb/article/view/5510/6298

Maula, N. I. I., \& Setyowati, S. (2016). Pengaruh Metode Bermain Berbasis Fun Cooking Terhadap Kemampuan Mengenal Bentuk Geometri Anak Kelompok A. PAUD Teratai, 5(2). Retrieved from https://jurnalmahasiswa.unesa.ac.id/index.php/paudteratai/article/view/14845

National Council of Teachers of Mathematics. (2000). Principles and standards for school mathematics. Reston, VA: National Council of Teachers of Mathematics.

National Research Council. (2009). Mathematics learning in early childhood: Paths Toward Excellence and Equity (C. T. Cross, T. A. Woods, \& H. Schweingruber, Eds.). Retrieved from http://math4all.onmason.com/wp-content/blogs.dir/1543/files/2014/09/Mathlearning-in-Early-Childhood.pdf

PAUD Jateng. (2015). Contoh Format Checklist Skala Capaian Perkembangan PAUD. Retrieved December 18, 2020, from https://www.paud.id/format-skala-capaianperkembangan-paud/

Rachmat, N. A., \& Sumiati, T. (2016). Peningkatan Kemampuan Mengenal Geometri Pada Anak Usia Dini Melalui Permainan Mencari Harta Karun. Metodik Didaktik, 11(1), 7181. https://doi.org/https://doi.org/10.17509/md.v11i1.3787

Safrina, K., Ikhsan, M., \& Ahmad, A. (2014). Peningkatan Kemampuan Pemecahan Masalah geometri Melalui Pembelajaran Kooperatif Berbasis Teori Van Hiele. Jurnal Didaktik Matematika, $\quad l(1), \quad 9-20 . \quad$ Retrieved from http://www.jurnal.unsyiah.ac.id/DM/article/view/1333/1214

Sarama, J. A., \& Clements, D. H. (2009). Early Childhood Mathematics Education Research: Learning Trajectories for Young Children (Studies in Mathematical Thinking and Learning) (1st ed.). New York: Routledge.

Sugiyono. (2019). Metode Penelitian Kuantitatif, Kualitatif dan R\& D. Bandung: Alfabeta. 